\begin{tabular}{|l|l|l||}
\hline \multicolumn{2}{|c|}{ PublisherInfo } \\
\hline \hline PublisherName & $:$ & BioMed Central \\
\hline \hline PublisherLocation & $:$ & London \\
\hline \hline PublisherImprintName & $:$ & BioMed Central \\
\hline \hline
\end{tabular}

\title{
Antithrombin III and sepsis
}

\begin{tabular}{||l|l|l||}
\hline \multicolumn{2}{|c||}{ ArticleInfo } \\
\hline \hline ArticleID & $:$ & 4322 \\
\hline \hline ArticleDOI & $:$ & $10.1186 /$ ccf-2001-73701 \\
\hline \hline ArticleCitationID & $:$ & 73701 \\
\hline \hline ArticleSequenceNumber & $:$ & 33 \\
\hline \hline ArticleCategory & $:$ & Paper Report \\
\hline \hline ArticleFirstPage & $:$ & 1 \\
\hline \hline ArticleLastPage & $:$ & 3 \\
\hline \hline & & RegistrationDate : 2001-12-6 \\
ArticleHistory & $:$ & Received \\
\hline \hline ArticleCopyright & $:$ & Oiomed Central Ltd2001-11-21 \\
\hline \hline ArticleGrants & $:$ & \\
\hline \hline ArticleContext & $:$ & 1305455 \\
\hline \hline
\end{tabular}


Richard Venn, ${ }^{\text {Affl }}$

Affl Worthing Hospital, UK

\section{Keywords}

Antithrombin III, outcome, sepsis

\section{Context}

Uncontrolled activation of the coagulation system may contribute to the mortality associated with septic shock. This phase III multicentre trial investigated the role of antithrombin III (ATIII), a serine protease inhibitor affecting multiple aspects of the coagulation cascade, in patients with severe sepsis and septic shock.

\section{Significant findings}

The baseline ATIII activity was approximately $60 \%$ in both groups. This rose to $180 \%$ in ATIII group at 24 hours; there was no change in the placebo group at 24 hours.

Overall mortality at 28 days was $38.9 \%$ in the ATIII group versus $38.7 \%$ in the placebo group; similarly, there was no difference at 90 days.

Statistical evidence for interaction between heparin and ATIII can be derived from multiple logistic regression analysis. There was a significant mortality benefit at 90 days for patients not receiving heparin: 352 (49\%) in the ATIII group versus $346(52.5 \%)$ in the placebo group $(P=0.03)$.

Overall there was no difference between groups except for bleeding events, which had an incidence of $22 \%$ in the ATIII group and $13 \%$ in the placebo group $(P<0.001)$; this was most marked in patients receiving concomitant heparin therapy.

\section{Comments}


The summary to this paper highlights the disappointment of this study: ATIII "joins a long list of promising experimental agents for sepsis that failed to show a significant benefit in a multicenter, randomised phase III clinical trial". Patients treated in this study with ATIII demonstrated lower ATIII activity (180\%) than was expected from preclinical trials (200-250\% activity), which may have contributed to the absence of clinical outcome benefit. Another explanation for this lack of benefit is that heparin competitively inhibits binding of ATIII for glycosaminoglycans on the endothelial surface of inflammatory cells, which would explain why those patients without concomitant heparin therapy had an outcome advantage with ATIII over placebo. Adverse bleeding events are obviously a concern in severe sepsis patients receiving ATIII. Despite the negative result, ATIII will continue to fascinate the intensivist, and it may be that a subgroup of severe sepsis patients will benefit from this therapy once the optimum dosage regime has been determined.

\section{Methods}

This was a double-blind, multicentre, phase III, randomised placebo-controlled trial in which 2314 patients with severe sepsis were randomised to receive 30,000 IU ATIII or placebo.

Exclusions included known bleeding disorders, and heparin therapy \&151; except low-dose $(<10,000$ IU/day) subcutaneous heparin or intravenous line flushing with heparin.

\section{Additional information}

\section{References}

1. Warren BL, Eid A, Singer P, Pillay SS, Carl P, Novak I, Chalupa P, Atherstone A, Penzes I, Kubler A, Knaub S, Keinecke H-O, Heinrichs H, Schindel F, Juers M, Bone RC, Opal SM, for the KyberSept Trial Study Group : High-dose antithrombin III in severe sepsis: a randomised controlled trial. JAMA. 2001, 286: 1869-1878. 